UDC 341.232.1(5)

DOI: https://doi.org/10.18485/iipe_ria.2020.71.1180.2

Biblid 0543-3657, 71 (2020)

Vol. LXXI, No. 1180, pp. 27-44

Review paper

\title{
THE SHANGHAI COOPERATION ORGANIZATION IN THE STRUCTURE OF THE GREATER EURASIAN PARTNERSHIP
}

\author{
Yury V. KULINTSEV ${ }^{1}$
}

\begin{abstract}
The article analyses the new directions of development of the Shanghai Cooperation Organization, examines the geopolitical reasons for their emergence, and also identifies the role and place of the SCO in the framework of the Greater Eurasian Partnership. With India and Pakistan joining the SCO, its capabilities began to expand, and new priorities appeared though not at the expense of traditional areas of responsibility - regional security and the fight against terrorism. The three-year period from 2015 to 2017 was a window of opportunity for the SCO in terms of choosing priorities for further development. The economic development begins to gain strength in the Organization. The SCO becomes the main platform for implementing economic integration in Eurasia, on the basis of which conjunction of the EEU and the Chinese Belt and Road Initiative will be implemented. On the margins of the SCO summit held in 2015 in Ufa the Development Strategy of the SCO until 2025 was adopted. This strategy focused on the economic and trade-related measures along with the issues of political interaction and cooperation in the field of security. Acting as one of the drivers of regional development, the SCO countries are making a concerted effort to create the necessary conditions for ensuring sustainable social and economic development. The new development directions of the SCO demonstrate that the Organization is able to quickly adapt to the new conditions of the changing world, while its participation in new formats of interaction is welcomed among countries of the Eurasian continent.
\end{abstract}

Keywords: SCO, Great Eurasian Partnership, Russia, China, Silk Road Economic Belt.

\footnotetext{
${ }^{1}$ Yury V. Kulintsev, Associate Researcher, North-East Asian Strategic Issues and SCO Center, Institute of Far Eastern Studies, Russian Academy of Sciences, Moscow, Russia.

E-mail: kulintsev.y@ifes-ras.ru.
} 


\section{INTRODUCTION}

The territory of Eurasia combines different countries with unique resources; their economic bases are able to successfully enlarge each other. All together, it creates a huge potential for cooperation and mutual development. The prerequisites for starting the contemporary processes of Eurasian integration began to evolve in the 2010s. During that period the countries of the region faced serious foreign policy challenges related to the tendency of strengthening the rivalry for economic and political leadership in Eurasia.

Almost each of the "big countries", including extra-regional players, introduced its own strategy of action in the region. Thus, in 2011 the State Secretary H. Clinton announced US ideas about the development of the region - The Strategy of the New Silk Road (Hormats, 2011, p. 12), in 2013 Chinese leader Xi Jinping introduced the initiative of the Silk Road Economic Belt. Russia also was one of the first countries which understood the necessity to speed up the integration efforts. In 2010 Russia became one of the founders of the Customs Union, which in 2015 transformed into the Eurasian Economic Union (EAEU). And after that Russia launched the idea of the Greater Eurasian Partnership (GEP) (Poslaniye Prezidenta, 2015).

Within the prescribed period the situation in the security field became complicated because of the growth of the terrorist threat in the region, which was considered to be the area of responsibility of the Shanghai Cooperation Organisation (SCO) and the upcoming GEP. The countries of the region had to consider additional security factors while discussing possible directions of regional development, the future of already existing integration projects, such as the SCO, as well as their plans to participate or not to in the sub-regional infrastructure projects of the Chinese Silk Road Economic Belt initiative.

In these conditions, the Shanghai Cooperation Organisation continued its activity in the international arena, remaining a classic example of the open regional organization. In 2020, the Organisation will mark the 19th anniversary of its establishment by the leaders of Russia, China, Kazakhstan, Kyrgyzstan, Tajikistan, and Uzbekistan. Initially, the organization focused on building an institutional framework, on joining their ranks with observers and dialogue partners. However, in the last few years, the SCO pays more attention to trade and economic cooperation and the processes of Eurasian integration.

The advancement of new conceptual paradigms for the development of Eurasia by the leading regional players has required an analysis of the geopolitical reasons for their nomination. In addition, it is necessary to analyse the conditions and possibilities of integration of the new development concepts with existing international organizations, in particular, with the SCO. 
This article aims to specify the role and place of the SCO within the Russian GEP initiative. To achieve this goal, the author has decided to concentrate on four research tasks: 1) to give an overview of Moscow's motives, on which it has relied when proposing the GEP idea; 2) to show possible points of intersection of mutual interests of the SCO and the new integration structure - the GEP; 3) to study the reaction of China as Russia's largest international partner to the GEP initiative; 4) to designate new possible vectors for the SCO development, in the context of Moscow's priorities in the Organization.

Every time while analysing the SCO development, we have to keep in mind the increased role of China in Eurasia and the world. Beijing has started to pursue a more active foreign policy in Central Asia and has become one of the main trade partners for the countries of the region. In Russia, the Eurasian territory has been always perceived as an important region where Moscow's strategic interests are dominated.

\section{THE ORIGINS OF THE RUSSIAN INTEGRATION PROJECT - GEP}

One of the reasons to introduce the idea of the Greater Eurasian Partnership, as well as the Chinese Belt and Road Initiative, was determined by the form of the current international order, where the countries of the West are dominated. Nevertheless, the changes of the US foreign policy shown during D. Trump's presidency and despite the claims of some experts that the positions of the West countries are weakening (Rolland, 2019, p. 9), i.e., the current narrative of the White House, is still directed against Moscow and Beijing and US policy is oriented to restrain economic development of Russia and China. The expansion of economic relations between Moscow and Beijing is the required prerequisite of social and political stability in Eurasia.

In 2015 there already were some announcements on the level of the top public officials that Russia successively supports the creation of the common economic space from Lisbon up to Vladivostok. At the same time, the growth of the interest from other countries and integration associations to develop cooperation with Moscow, was noted (Povolotskiy, 2015).

Nowadays, the regional integration in the Eurasian region is implemented by the two main players - Russia and China via mechanisms of the Eurasian Economic Union, via the Chinese Belt and Road initiative and via the Shanghai Cooperation Organization.

The fact that there are several large-scale integration projects in Eurasia which have intercrossing member states and similar declared aims, it requires to find out a new approach to set up a trend of integration processes development in Eurasia. 
The combination of these factors has stipulated the initiation of the idea of the Greater Eurasian Partnership. The GEP is aimed to protect the international positions of Moscow and strengthen its regional influence. From the very beginning, the GEP was oriented to support political stability and security, to create conditions for trade-economic, finance, and investment development. At the same time, the GEP reflects the perception of Russian political leadership about the future regional order.

The experts of the international discussion club "Valdai" were the first to discuss the idea of the GEP on a conceptual level. In the series of reports "Towards Great Ocean", there was justified the position why the members of the above mention integration projects were faced with the same internal and external challenges and why they were motivated to coordinate social and economic development. It was the basis of the GEP's idea, and it helped to increase the level of coherence of the countries that were interested in the Eurasian regional development (K Velikomuokeanu, 2019, p. 23-25).

The foreign political experts believe that the materials of the "Valdai" club reports underlie the idea of the Greater Eurasian Partnership that has been introduced by Russian President V. Putin in 2016 during the St. Petersburg International Economic Forum (Li, 2017, p. 30). V. Putin proposed to create the Greater Eurasian Partnership, which was involving the member-states of the SCO, the EAEU, the CIS countries, Iran, and a number of other states. The work of the GEP had to be oriented to create a new format of international cooperation in Eurasia with the support of the conjunction of Eurasian integration projects with the Chinese BRI (Stenogramma vystupleniya, 2016).

\section{THE SPHERES OF COMMON INTERESTS BETWEEN THE SCO AND THE GEP}

The expansion of the geographical scope of the GEP over the whole Eurasian region, i.e., over the borders of the former Soviet republics, this expansion reflects the understanding of the Russian political elites that the EAEU itself is not enough to build a full-scale system of regional integration in Eurasia. In order to reach game-changing indicators of economic development, it is required to attract powerful Asian economies.

Some Chinese political experts say that Russia is providing the regional integration within the GEP as a new geo-economic strategy with the ultimate goal to reconstruct the common economic, political and military space within the borders of the former USSR, but in a new form (Zhao and Xiao, 2017, p. 22). It is important to note, that they believe that the Ukrainian crises of 2014 is interpreted as a key 
milestone after which Moscow's foreign focus was reoriented from Greater Europe to Greater Eurasia.

Meanwhile, the Russian "pivot to East" is not a result of the US and Western countries' geopolitical efforts only (Kulintsev, 2016). The pivot was a strategic choice of Russia. The basis for the pivot was set up in early 2001 when the Treaty of friendship, neighbourliness, and co-operation between Russia and China was signed. Later, Russian-Chinese contingence was the consequence of the shift of global focus of political and economic development into the Asia-Pacific Region. It opened for Moscow new options for cooperation and development, including the framework of the Greater Eurasian Partnership.

A number of Chinese experts believe that Russian can refer to the Chinese BRI as potentially threatening to Chinese interests in the neighbouring countries (Jiao, 2018). The growing asymmetry of economic capacity between Russia and China too obvious in the region of Central Asia can make Moscow's displeased with the status of "younger brother" in the region.

The implementation of the GEP project allows Russia to minimize the risks of weakening its international positions and to guarantee that the Central Asia region continues to be a traditional sphere of Moscow's influence. The Russian fundamental interests coincide with the Chinese understanding of regional development, it explains why the GEP and the BRI have more common similarities than differences (Yang, 2016).

Maintaining security and stability in the Central Asian region, which belongs to the SCO's area of responsibility, is the common interest for Russia and China. Experts agreed that currently, Moscow's combined impact in Central Asia is greater than Beijing's one (Zhao and Xiao, 2017, p. 23). Thus, the GEP project becomes more interesting for these international players, including the SCO and other international structures, which want to use Russian experience and develop cooperation with Central Asian countries.

One of the key factors of GEP's successful development is mutually beneficial cooperation between the SCO countries. The SCO is one of the main structural components of the GEP (Luzianin and Klimenko, 2019, p. 105). The GEP is not a rival for the Chinese Silk Road Economic Belt. It tries to play the role of a "link" for already existed integration formats in Eurasia, including cooperation within the SCO and the EAEU.

At the same time, the development of the SCO, the entry of India and Pakistan into the SCO as full members led to the expansion of its capabilities and the identification of new priorities, but not at the expense of traditional areas of responsibility - regional security and counterterrorism. 


\section{THE SCO IN THE RUSSIAN FOREIGN POLICY}

The three-year period from 2015 to 2017 became a window of opportunity for the SCO in terms of prioritizing further development and correlation between this choice and changes of the Eurasian space. In approaching the 15-year milestone, the SCO occupies the position of an important actor in the international arena. The organization is an observer in the UN General Assembly and has two permanent executive bodies - the SCO Secretariat and the Executive Committee of the Regional Anti-Terrorist Structure (RATS). As part of the RATS, a mechanism of cooperation with observers and dialogue partners operates effectively. Also, a mechanism for accepting new members has been launched, which indicates its international demand and geopolitical potential. Moreover, from then on, the economic direction of the SCO development began to gain more strength.

In May 2015, leaders of Russia and China underlined in a joint statement that the SCO would become the main platform for the implementation of economic integration in Eurasia. The conjunction of the Eurasian Economic Union and the Chinese Silk Road Economic Belt (SREB) initiative will be implemented on this platform. Moreover, this work will be carried out in bilateral and multilateral formats of interaction (Sovmestnoe zayavlenie RF i KNR, 2015). Two months later, on the margins of the SCO summit held in 2015 in Ufa, the heads of member states adopted the Development Strategy of the SCO until 2025, which focuses on trade and economic cooperation measures along with issues of political interaction and security cooperation. In the medium term, they comply with the objectives of the Silk Road Economic Belt initiative. These include the formation of a favourable investment and business climate, support for business initiatives, implementation of projects in priority areas of cooperation and development of infrastructure, cooperation in the development of production capacities, promoting integration into the global economy, minimizing the negative effects of globalization and crises in the international economic processes on national economies. Within the framework of the SCO, practical measures are planned for the implementation of specific economic and investment projects (Strategiya razvitiya, 2015).

Speaking at the SCO Summit in Ufa in July 2015, President Putin expressed the position of the Russian side on the prospects for trade and economic cooperation and joining the Chinese SREB initiative. He claimed: "We place particular emphasis on continuing to develop trade and economic cooperation within the SCO. It is clear that if we join our efforts together, we can handle crises in the global economic and financial systems more effectively and easier overcome various restrictions and barriers. We think it is important to develop our cooperation in ensuring food, transport, energy and financial security. We are ready to work closely together to coordinate and build links between the two integration projects - 
the Eurasian Economic Union and the Silk Road Economic Belt" (Stenogramma zasedaniya RF i KNR, 2015).

In 2016, the potential of the SCO was again in demand as part of a new integration project - the Greater Eurasian Partnership, which was announced to the international community on the margins of the St. Petersburg International Economic Forum (Stenogramma vystupleniy, 2016). President Putin offered to create the Greater Eurasian Partnership involving the SCO member states, the EAEU, including China, India, Pakistan, Iran, the CIS countries, and a number of other states. The activity of the above-mentioned partnership should be aimed at the establishing a new format of international cooperation in Eurasia by supporting the idea of the conjunction of the Eurasian integration with the Chinese SREB initiative.

This means that the new development direction of the SCO began to establish, implying that eight countries should be one of the main pillars of the new world order in Eurasia.

\section{THE COOPERATION OF RUSSIA AND CHINA ON EURASIAN INTEGRATION}

From an economic point of view, the GEP and the Chinese BRI are aimed to develop Eurasian transport corridors, which support infrastructure integration and stimulate regional trade. From a geopolitical point of view, the potential conflict between China and Russia is so small that it cannot provide any serious negative impact on the development of both projects in the foreseeable future.

Compared to the Russian GEP and the EAEU, the Chinese BRI is more attractive in terms of investment possibilities. Beijing is ready to spend large financial resources on a variety of projects. The BRI is an inclusive project. That is why so many countries, including Russia, joined it or announced that supported it.

In 2015, during the meeting of Russian President V. Putin and Chinese leader $\mathrm{Xi}$ Jinping was signed the Joint statement for cooperation on the conjunction of the EAEU and the Silk Road Economic Belt (Sovmestnoe zayavlenie RF i KNR, 2015). It was the first step that showed the intention of both countries to work together and strengthen regional economic integration. This intention became the guarantee of the Eurasian integration, of peace and stability in the region (Xinhuanet, 2015). The joined investments, infrastructure development and plans to create a Free Trade Area between the EAEU and China - all these factors stimulate regional economic development. As a result, it generates new dialogue platforms that allow discussing practical measures and initiatives. The term "conjunction" (duijie) characterizes the consolidation process of the integration efforts of both countries. 
In 2016 during V. Putin's official visit to China, two leaders of Russia and China highlighted in the joint statement that Moscow and Beijing were ready to coordinate its strategies of Eurasia development and ready to promote the idea of the Eurasian comprehensive partnership which is based on the principals of openness, transparency and respecting the mutual interests (Sovmestnoe zayavlenie RF i KNR, 2016). It was also announced the priority to involve the SCO, the EAEU and the ASEAN in the Eurasian integration process. The governments of both countries were assigned to develop measures for the implementation of these initiatives.

One year later, in July 2017, during Xi Jinping's official visit to Russia, both sides announced the further strengthening of interaction within the framework of comprehensive partnership and strategic cooperation between Moscow and China (Sovmestnoe zayavlenie RF i KNR, 2017). The Russian Ministry of economic development and the Chinese Ministry of Commerce signed a joint statement on the technical and economic feasibility of the Agreement on Eurasian economic partnership (Dokumenty, podpisannye, 2017). After bilateral consultations between Russian and Chinese experts, both sides reached a consensus in interpreting the principles of "sovereign equality and non-interference in the internal affairs", as well as mutual respect of the "chosen development ways" (Li, 2018, p. 97).

In 2019 during the official meeting, the heads of Russia and China signed a joint statement that confirms that the Chinese BRI and the Russian GEP are able to develop in parallel, be coordinated, and are to promote the development of the SCO and other regional unions, bilateral and multilateral integration projects in Eurasia (Sovmestnoe zayavlenie RF i KNR, 2019). It did not mean that Russia joined the Chinese initiative. It meant the joint and parallel implementation of the BRI and the GEP, oriented to build a new model of international cooperation in Eurasia.

The legal footwork of the GEP is promoted by Russia under the support of the Chinese side. During the exchange of high-level visits, the corresponded phrases are included in the joint declarations. Moreover, both sides have created an effective mechanism of regular visit exchanges - from the meeting of the heads of the states to the consultations of the heads of departments in Ministries.

The future of Eurasia was on the agenda at the global forum "One Belt, One Road" held in 2017 and in 2019 in Beijing, which gathered a dozen heads of foreign states and governments and representatives of more than 100 international organizations, including the SCO. The leaders noted that the international community was on the threshold of forming rules of new world development. In this process, the leading SCO countries consider themselves as global responsible powers, which could take part in all international affairs and make a significant contribution to the world development and the global economy (Xi Jinping's speech, 2017). 
China pays high attention to the SCO development and since its establishment wants to boost the Organization's economic potential and to include it into the integration formats. The Chinese experience shows that Beijing is ready to adopt all aspects of the SCO's enrolment in regional economic integrations. China has been precisely, methodically and gradually entering into economic integrations by building a network of international relations, contributing to its development strategy and correcting irregularities in its economy, while at the same time solving political problems (Zakić, 2019, p. 44).

One of the focal points of any state foreign policy is the question of territorial disputes irrespective of its geographical size, economic opportunities, or geopolitical ambitions. At the same time, in the modern world, the scenario of boundary change in Central Asia involving the use of force as a possible option for China to resolve territorial disputes is hardly probable. None of the parties, including neighbouring countries, are interested in intensifying territorial claims and initiating a real conflict. Despite the apparent advantages, a guaranteed response from the international community jeopardizes all benefits for the potential aggressor (for example, Beijing) from possible territorial acquisitions.

It should be added that there is a reliable international system to control and monitor the security situation in the region. The system has been established with the direct participation of Russia, and there are at least two international organizations - the SCO and the CSTO - who provide guarantees and responsibility for the security situation. Thus, the international community has enough military options and the political power to restrain any regional player from aggressive actions.

At the same time, we can observe a lot of civilized solutions to how territorial issues have been settled in Eurasia. They include - diplomatic negotiations, longterm lease land, the establishment of joint administration management, and so on. For example, in 1898, China leased its Hong Kong territory to Great Britain for a period of 99-years. In 1987 was signed a Joint Declaration on the Question of Macau between Portugal and China. The document provided guarantees that the Macau Special Administrative Region had a high degree of autonomy with local administration and independent legislative power (Edmonds, 1999). Thus, Macau started its way back to China. After the PRC has become a successful economic power, Beijing has preferred Chinese diplomats to speak about territorial disputes, rather than Chinese guns.

It should be pointed out that implementing its BRI, China has never presented it as a charity project. Moreover, the initial goal was to provide new drivers for its economy to develop the Central and Western regions of China. All foreign countries participating in the initiative have expressed their desire to join it on the terms of mutually beneficial development. By accepting China's offers and agreeing to its 
loans and investment projects, any of the countries had the opportunity to assess the risks and not participate in them, or to make a choice and develop their own economy on the terms of other financial institutions, such as Western ones. In this case, China acts in the Central Asian region like most major powers interested in strengthening their positions and promoting their political, economic, and humanitarian agenda.

Possible allegations of Beijing of concluding economic contracts on bonded terms should also be addressed to officials of the "affected" countries who agreed to these proposals from the Chinese side. At the same time, if it appears that one of the parties has not acted in its national interests, this is more a problem of the internal state structure of a particular country and its attitude to the work of its own officials, and to a much lesser extent - a claim to the development of bilateral relations with China.

There is an example of using the foreign policy agenda in the internal political struggle. There was a statement of the leader of the opposition party of Tajikistan, R. Zoirov, who accused China of moving the border line 20 kilometres deeper into the territory of Tajikistan.

On the eve of the presidential elections in 2013, Tajikistan's opposition once again tried to "accuse authorities of the surrendering land to China" in the framework of the 2002 border demarcation agreement. China claimed 28 thousand square kilometres of Tajikistan's territory, but as a result of the negotiations, it received just over 1 thousand square kilometres of high-altitude land unsuitable for life, without the proven volumes of large deposits. The results of negotiations can be evaluated in different ways, but each country has the right to seek convenient forms of dispute resolution and debt repayment. In addition, this agreement was ratified by the government of Tajikistan only in 2011. The official representative of the Ministry of Foreign Affairs of Tajikistan described the statement of the oppositionist as a provocation due to the fact that the author acts in his own interest. Later, it was revealed that Zoirov's statement refers to 2011 and was "made two years ago and published just now". According to R. Zoirov, he determined the distance to the border based on the statements of local residents. The official authorities of Tajikistan, China, Russia and other regional powers ignored information about China's occupation of Tajikistan's territory as unreliable (Kulintsev, 2020).

Recognizing the high public sensitivity to the transfer of land of one state to repay credit obligations to another state, it is necessary to proceed from the analysis of the content of specific international agreements, the motives for signing them by the current authorities, and the national interests of the parties involved. Otherwise, it is likely to get a distorted interpretation of key events in line with the 
populist rhetoric of an unknown blogger or to be the recipient of information propaganda carried out by major powers competing for regional influence.

Summarizing the above mentioned, it can be noted that Moscow and China are committed to coordinating efforts on the integration of the GEP in the system of international relations. Both sides understand that full format strategic cooperation is required for the successful implementation of the GEP.

\section{THE INTEGRATION OF THE SCO IN THE GREATER EURASIAN PARTNERSHIP STRUCTURE}

The Russian side called for combining the potential of all the integration formats like the EAEU, the OBOR, the SCO and the ASEAN to build the foundation for a larger Eurasian partnership (Vystuplenie V. Putina, 2017).

The new SCO's function is highlighted in the proposed scenario for the creation of a new integrated structure in Eurasia -the SCO should link the SREB and the EAEU. In this case, Russia pursues its geopolitical goals, trying to align the asymmetry of economic opportunities between Moscow and Beijing in Central Asia and keep this region as a sphere of traditional influence of Russia without damaging the processes of Eurasian integration.

Fundamental international organizations recognize the importance of the SCO in the regional and global agenda. The resolution on cooperation between the UN and the SCO, adopted at the 73rd session of the UN General Assembly, gave an additional impetus to the development of the Organization. The UN Secretary-General A. Guterres expressed confidence that the UN and the SCO would join their efforts and make a positive contribution to improving the lives of people in Eurasia, strengthening regional cooperation at all levels(Generalnyj sekretar SHOS, 2020).

It also means that the GEP is not a rival for the BRI, and does not challenge a tension or a conflict between Moscow and Beijing. The analysis of the actions of political leaders of both countries shows that, in fact, the contrary situation takes place. While understanding the risks of rivalry in Eurasia, Russia and China demonstrate self-confidence and coherence of actions trying to avoid unnecessary rivalry and focusing on the cooperation, which successfully allows conjunct their flagship initiatives.

The geography of the central part of Eurasia provides the SCO participants with a strategic advantage in implementing integration projects. Almost no one of the SCO members, observers or dialogue partners opposed the idea of participating in the Greater Eurasian Partnership. Most SCO countries also supported China's Belt and Road initiative. On the one hand, the heads of the SCO members see the economic and geopolitical prospects of new integration projects. On the other 
hand, the initiators of the Eurasian integration understand the importance of the incorporation of their own projects into the SCO agenda. For almost two decades the SCO has successfully acted as a guarantor of peace and stability in the region. In other words, it provides vital conditions for the sustainable economic development of the member states.

The uniqueness of the geopolitical and geoeconomic situation of the SCO countries in the system of international relations in Eurasia led to the signing of the agreement between the governments of the SCO member states on the creation of favourable conditions for international road freight, which came into effect in January 2017 (Shanhajskaya organizaciya sotrudnichestva, 2017).

In November 2019, the SCO Council of Heads of State adopted the Concept of interaction between the railway administrations (Sovmestnoe kommyunike, 2019). This document became the basis for the creation of general legal provisions in the field of railway transport, which fits the common direction of development of the GEP integration potential and provides the floor for unleashing the SCO transit potential through transcontinental freight in Eurasia. According to experts, annually more than 23 million containers are sent from China to Southeast Asia and Europe, and the volume of container cargo traffic from China to Europe over the previous 9 years has shown a 40-fold increase (Generalnyj sekretar SHOS, 2020).

The improvement of transport infrastructure and the creation of optimal cargo transportation routes are the priorities for the development of the SCO and the formation of the GEP. The SCO has the Special Working Group on Customs Cooperation, which in November 2019 promoted the signing of the Memorandum between the customs services on mutual integration of national transit systems by the Council of Heads of Government (Sovmestnoe kommyunike, 2019). In this context, the efforts of the SCO member states to contribute to improving transport connectivity in Eurasia, allowing to implement innovative technological solutions and develop multimodal transport and logistics centres within the GEP.

The SCO is constantly searching for new ways of cooperation. As one of the drivers of global economic development, the participating countries are making concerted efforts to create the necessary conditions for ensuring sustainable social and economic development in Eurasia.

In November 2019, in order to enhance economic cooperation and improve the investment climate, the Council of Heads of Government approved the updated Program of multilateral trade and economic cooperation of state members of the SCO (Sovmestnoe kommyunike, 2019). The program is aimed at the consistent strengthening of an open, transparent and non-discriminatory multilateral trading system in the Eurasian space. According to the SCO Secretariat, in 2018 the SCO's economic importance was also determined by the fact that the SCO member states produced GDP worth over 18 trillion dollars (or more than 
$22 \%$ of world GDP). It is projected that by 2025 this figure will reach $38-40 \%$ (Ran, 2019, p. 21).

The promotion of trade and economic cooperation allows to balance the previous direction of development of the organization focused primarily on ensuring political interaction and regional security. The development of the SCO is becoming more stable, which contributes to the growing importance of the SCO in the international arena and also increases the interest of participants in mutual development.

\section{CONCLUSIONS}

Currently, one of the main challenges is to maintain new development directions of the SCO in the difficult external environment. After the enlargement of the SCO, the total power and influence of the Organization have increased significantly, allowing it to set more ambitious goals objectives. The priorities announced by the Russian presidency in 2019-2020 completely correspond with the SCO needs.

The current direction of the SCO development suits all member countries, thus one of the key points for Moscow will be to ensure continuity in the work of the Organization. Firstly, the efforts of the party holding the presidency will be focused on strengthening the SCO's position in the sphere of maintaining security and stability. Fighting against "three evils" and drug trafficking is a traditional area of cooperation for the SCO within the framework of the Regional Anti-Terrorist Structure of the SCO. In addition, the work will continue on resolving crisis situations and ensuring the peaceful settlement of conflicts near the external borders of the SCO countries in the context of the problems in Syria and Afghanistan as well as the situation around the Iranian nuclear program.

Secondly, Moscow sees great opportunities in expanding economic cooperation, primarily in transport and logistics, infrastructure, science and technology, and innovation. It is expected that special emphasis will be placed on strengthening inter-regional cooperation within the SCO. Among the planned events, Russia announced the First Forum of Heads of Regions of the SCO member states.

The development of cultural and humanitarian ties, the promotion of common moral and ethical values, intensification of cooperation in the fields of education, health, ecology, culture, tourism and youth contacts will be continued. It is planned to hold a series of large-scale events dedicated to the 75th anniversary of the victory in World War II.

Thirdly, the Russian side plans to consolidate the SCO member states and deepen foreign policy coordination in order to harmonize positions on topical international and regional issues and develop joint initiatives. It is expected that the SCO countries will strengthen coordination of positions within the UN as well as 
increase practical cooperation with ASEAN, the CSTO, the CIS, the ECO and the EEU, including the exchange of experience and promoting of joint projects and initiatives (Tarasenko, 2019, p. 2).

At the same time, the Russian presidency priorities include new directions for the Organization's development. Firstly, this implies promoting synergy between the potentials of national development strategies and multilateral integration projects. In this context, the goal is to establish the SCO as one of the pillars of the space of broad, equal and mutually beneficial cooperation in Eurasia in the interests of ensuring reliable security and sustainable development within the framework of the idea of a Greater Eurasian partnership. Secondly, Moscow plans to launch inter-parliamentary cooperation in the SCO by creating a mechanism for interaction between the legislative bodies of the SCO member states, which also allows advancing the practical implementation of the Eurasian integration initiatives (Prioritety predsedatelstva, 2020).

In relation to the outbreak of a novel coronavirus in the world, in the first quarter of 2020, the Shanghai cooperation organization began to study proposals for a rapid response to infectious disease outbreaks. In particular, the SCO Secretariat sent a number of proposals to the relevant departments of the member states for consideration. They include the development of a multilateral mechanism for prompt notification in case of the emergence of epidemic hotbeds which have the potential for wide dissemination.

At the same time, already in 2018, the organization noted with deep concern the persistent threat of epidemics, including the flu, severe acute respiratory syndrome, and other particularly dangerous infections. At the summit in Qingdao (China), the Heads of State of the SCO made the Statement on joint efforts against the threat of epidemics in the SCO space and pointed out the resulting need to enhance the sanitary and epidemiological safety and the protection of public health, which is vital for the sustainable development and prosperity of the regional countries (Statement by the Heads, 2018).

This direction is also becoming one of the new development vectors of the organization. Within the SCO, the countries develop close ties with each other at the level of heads of ministries and departments responsible for health and the epidemiological situation. A number of documents have already been adopted, and working mechanisms have been created to ensure cooperation between the relevant organizations of the SCO countries in the field of health. The meetings of Ministers of Health and Heads of Services of the SCO member states responsible for the maintenance of the population's sanitary and epidemiological wellbeing are held.

Despite the fact that a number of SCO events were postponed due the spread of the epidemic, the existing mechanisms of cooperation allowed to continue holding meetings in the format of video-conference. The new development 
directions of the SCO demonstrate that the Organization is able to quickly adapt to the new conditions of the changing world, and its participation in new formats of interaction is in demand among the countries of the Eurasian continent.

\section{List of references}

Huaxia, Z., China, Russia Agree to Integrate Belt Initiative with EAEU Construction, (2015, May 9). Retrieved from http://www.xinhuanet.com/ english/2015-05/09/c_134222936.htm.

Dokumenty, podpisannye po itogam oficial 'nogo vizita Predsedatelya KRN v RF (Documents signed during Chinese president's official visit to Russia). (2017, July 4). Retrieved from http://www.kremlin.ru/supplement/5217. (In Russian).

Edmonds, R., and Yee, H. (1999). Macau: From Portuguese Autonomous Territory to Chinese Special Administrative Region. The China Quarterly, 160: 801-817. doi:10.1017/S030574100000134X

Full text of Xi Jinping's speech at opening of Belt and Road forum, (2017, May 14). Retrieved from https://america.cgtn.com/2017/05/14/full-text-ofpresident-xis-speech-at-opening-of-belt-and-road-forum

Generalnyj sekretar SHOS vystupil na 82-j sessii Komiteta po vnutrennemu transport Evropejskoj ehkonomicheskoj komissii OON (SCO Secretary General delivered a speech during the 82-nd session of UN Committee on internal transport of European economic commission), (2020, February 26). Retrieved from http://rus.sectsco.org/news/20200226/630345.html.(In Russian).

Hormats, Robert D. (2011, July). The United States’ «New Silk Road» Strategy: What is it? Where is it Headed?.Retrieved from http://www.state.gov/e/rls/ $\mathrm{rmk} / 2011 / 174800 . \mathrm{htm}$.

Jiao Yiqiang (2018).You RenZhiFenqi Dao HezuoGongshi(From Cognitive Differences to Cooperation Consensus), DangdaiYatai(Contemporary AsiaPacific), Vol. 4.Retrieved from https://www.ydylcn.com/zjgd/334409.shtml.(In Chinese).

K Velikomu okeanu (2019). Xronika povorota naVostok. Sbornik dokladov Valdajskogo kluba (Towards Great Ocean. Chronicles of the Russian pivot to Asia. Valdai club's book of reports), Moscow: Fond "Valdaj".(In Russian).

Kulintsev, Yury (2016, April 7). Rossiya povernulas k Kitayu vserez i nadolgo (Russia has turned to China seriously and for the long haul). Retrieved from http://russiancouncil.ru/turn2china. (In Russian).

Kulintsev, Yury (2020, September 4). Territorial disputes in Central Asia: myths and reality. Retrieved from https://russiancouncil.ru/en/analytics-and-comments/ 
columns/asian-kaleidoscope/territorial-disputes-in-central-asia-myths-andreality/.(In Russian).

Li Yongquan (2018). The Greater Eurasian Partnership and the Belt and Road Initiative: Can the Two Be Linked? Journal of Eurasian Studies,9 (2), 94-99.

Li Ziguo (2017). Da Ouya huobanguanxi: chongsu Ouya xin zhixu (Greater Eurasian Partnership: Reshaping the Eurasian Order?), Guoji Wenti Yanjiu (International Studies), 1 (25), 37, 25-37. (In Chinese).

Luzianin, S.; Klimenko, A. (2019).SotrudnichestvoRossii i Kitaya v ShOSporealizaciikoncepciiBol`shogoevrazijskogopartnerstva(Cooperation of Russia and China in SCO on implementation of the Greater Eurasian partnership concept), Kitaj v mirovoj i regionalnoj politike (China in World and Regional Politics), Issue XXIV. Moscow: IDV RAN, (In Russian).

Poslaniye Prezidenta Federalnomu Sobraniyu RF (President's message to Federal Assembly of the Russian Federation), (2015, December3).Retrieved from http://www.kremlin.ru/events/president/news/50864.(In Russian).

Povolotskiy G. (2015, November 24). Integratsiya integratsiy (Integration of integrations), Mezhdunarodnaya zhizn (The International Life). Retrieved from https://interaffairs.ru/news/show/14197.(In Russian).

Prioritety predsedatelstva Rossii v SHOS (Priorities of Russia's SCO Presidency), (2020). Retrieved from https://sco-russia2020.ru.(In Russian).

Ran, Shanchuan (2019). Golos SHOS slyshen vsemu miru (SCO voice is heard by the world), Kitaj(China), 12 (170), 20-21.

Rolland, Nadège (2019). A China-Russia Condominium over Eurasia, Global Politics and Strategy, Washington: International Institute for Strategic Studies, 61 (1), 7-22.

Rossiya i Kitaj: partnerstvo v kontekste vy'zovov bezopasnosti i razvitiya v ATR (Russia and China: partnership in the context of challenges to security and development in the APR), (2020, April 16). Retrieved from https://russian council.ru/projects/bilaterial/russia-china.(In Russian).

Shanhajskaya organizaciya sotrudnichestva (Shanghai Cooperation Organization), (2017). Retrieved from https://www.mintrans.ru/activities/69/92.(In Russian).

Sovmestnoe kommyunike po itogam vosemnadcatogo zasedaniya Soveta glav pravitel'stv SHOS (Joint communique on the results of the eighteenth meeting of the Council of Heads of Governmentof the Member States of the SCO), (2019, November 2).Retrieved from http://rus.sectsco.org/documents/.(In Russian).

Sovmestnoe zayavlenie RF i KNR (Joint Statement of Russia and China), (2015, May 8).Retrieved from http:/ /www.kremlin.ru/supplement/4971.(In Russian). 
Sovmestnoe zayavlenie RF i KNR (Joint Statement of Russia and China), (2019, June 5).Retrieved from http:/ /www.kremlin.ru/supplement/5413.(In Russian).

Sovmestnoe zayavlenie RF i KNR.(Joint Statement of Russia and China), (2016, June 25). Retrieved from http:/ /www.kremlin.ru/supplement/5100.(In Russian).

Sovmestnoe zayavlenie RF i KNR.(Joint Statement of Russia and China), (2017, July 4). Retrieved from http://www.kremlin.ru/supplement/5218.(In Russian).

Statement by the Heads of the SCO Member States on Joint Efforts Against the Threat of Epidemics in the SCO space, (2018, June 10). Retrieved from http://rus.sectsco.org/documents/.(In Russian).

Stenogramma vystupleniya V.Putinana PMEF-2016 (Putin's verbatim report during SPIEF-2016), (2016, June 17). Retrieved from https://rg.ru/2016/06/17/regszfo/stenogramma-vystupleniia-vladimira-putina-na-pmef-2016.html.(In Russian).

Stenogramma zasedaniya Sovetaglav gosudarstv - uchastnikov SHOS v rasshirennom sostave (Verbatim report of the meeting of the Heads of the SCO Member States in an extended format), (2015, July 10).Retrieved from: http://www.kremlin.ru/events/president/transcripts/49908.(In Russian).

Strategiya razvitiya Shankhajskoj organizacii sotrudnichestva do 2025 goda (The Strategy of SCO development till 2025), (2015, July 10). Retrieved from: http://static.kremlin.ru/media/events/files/ru/a3YPpGqLvQI4uaMX43lMkr MbFNewBneO.pdf.(In Russian).

Tarasenko, P. (2019). Rossiya uderzhivaet SHOS ot ehgoizma (Russia keeps SCO away from egoism), Kommersant (Businessman), 102 (2), p. 2.

Vystuplenie V.Putina na ceremonii otkrytiya mezhdunarodnogo foruma «Odin poyas, odin put'» (Putin's speech during opening ceremony of "One Belt, One Road" international forum ), (2017, May 14). Retrieved from: http://www.kremlin.ru/events/president/news/54491.(In Russian).

Yang Lei (2016, January 28). Eluosi “Da Ouya" vs Zhongguo "YidaiYilu" (Russia's Greater Eurasia vs China's Belt and Road).Retrieved from https://pit.ifeng.com /a/20180126/55485771_0.shtml?_cpb_xinxiliu_xgti.(In Chinese).

Zakić, K. (2019). China's economic integrations policies in Eurasia.In Аушан Пророковић и Ана Јовић Аазић (Ed.), Интеграциони процеси у Евроазији,(13-45).БеограА, Институт за међународну политику и привреду.

Zhao C. and Xiao W. (2017).Zhongguo Ying RuheHuiyingPujing de "Da OuyaHuobanGuanxi” Jihua' (How Should China Respond to Putin's 'Greater Eurasian Partnership' Plan), JingiiYanjiuDaokan(Economic Research Guide), (6), 18-25.(In Chinese). 


\section{ŠANGAJSKA ORGANIZACIJA ZA SARADNJU U STRUKTURI VELIKOG EVROAZIJSKOG PARTNERSTVA}

Apstrakt: Članak analizira nove pravce razvoja Šangajske organizacije za saradnju, ispituje geopolitičke razloge njihovog nastanka, te takođe identifikuje ulogu i mesto ŠOS-a u okviru Velikog evroazijskog partnerstva. Sa pridruživanjem Indije i Pakistana ŠOS-u, njegove sposobnosti su uvećane, a novi prioriteti su se pojavili, nešteteći tradicionalnim područjima odgovornosti - regionalnoj bezbednosti i borbi protiv terorizma. Trogodišnji period od 2015. do 2017. godine bio je prilika za ŠOS u pogledu izbora prioriteta za dalji razvoj, dok se fokus organizacije premešta na ekonomski razvoj. ŠOS postaje glavna platforma za sprovođenje ekonomske integracije u Evroaziji, na osnovu koje će se sprovoditi povezivanje EEU i kineske Inicijative Pojas i put. Na marginama samita ŠOS, održanog 2015. godine u Ufi, usvojena je Strategija razvoja ŠOS do 2025. godine, koja se fokusirala na ekonomske i trgovinske mere, zajedno sa pitanjima političke interakcije i saradnje u oblasti bezbednosti. Delujući kao jedan od pokretača regionalnog razvoja, države ŠOS-a ulažu zajedničke napore da stvore neophodne uslove za osiguranje održivog socijalnog i ekonomskog razvoja. Novi pravci razvoja ŠOS pokazuju da je ova organizacija u stanju da se brzo prilagodi novim uslovima sveta koji se menja, dok je njeno učešće u novim formatima saradnje priželjkivano među zemljama evroazijskog prostora.

Ključne reči: ŠOS, Veliko evroazijsko partnerstvo, Rusija, Kina, Ekonomski Pojas puta svile.

Received: 30/08/2020

Accepted: 10/10/2020 